\title{
Recurrent selection method for improvement of lutein and zeaxanthin in orange waxy corn populations
}

\author{
Watanyoo Khamkoh ${ }^{1}$, Danupol Ketthaisong ${ }^{1,3}$, Khomsorn Lomthaisong ${ }^{2}$, Kamol Lertrat ${ }^{1,3}$, Bhalang \\ Suriharn ${ }^{1,3 *}$ \\ ${ }^{1}$ Department of Agronomy, Khon Kaen University, Khon Kaen 40002, Thailand \\ ${ }^{2}$ Department of Biochemistry, Khon Kaen University, Khon Kaen 40002, Thailand \\ ${ }^{3}$ Plant Breeding Research Center for Sustainable Agriculture, Khon Kaen University, Khon Kaen 40002, Thailand
}

\section{Corresponding author: bsuriharn@gmail.com}

\begin{abstract}
The information on the responses to simple recurrent selection for yield and total carotenoid content in orange waxy corn is lacking. The objectives were to evaluate the responses to simple recurrent selection for two cycles for yield and carotenoids of orange waxy corn population and to investigate the correlations between color parameter with carotenoids in waxy corn kernels. Parental sources of germplasm with differences in kernel colors and levels of disease resistance were used for generation of a base population of orange waxy corn. A simple recurrent selection for superior phenotypes was practiced on this population for two selection cycles. Cycle 0 (C0), C1 and C2 were evaluated for two locations in 2016. The cycles showed significant differences for most traits except for plant height. The locations contributed to large portions of total variation in total yield, whereas selection cycle contributed to large portions of total variations in lutein, zeaxanthin, $\beta$-carotene and total carotenoid content and color parameter $\left(\mathrm{h}^{\circ}\right)$, indicating that selection for carotenoids would be possible. Simple recurrent selection for two cycles increased total yield and husked ear weight of $23.2 \%$ and $15.0 \%$, respectively. Simple recurrent selection for two cycles also increased lutein, zeaxanthin, $\beta$-carotene and total carotenoid content with increasing percentages ranging from 18.5 to $196.6 \%$. The results indicated that population improvement by simple recurrent selection could be useful in increasing these traits. Color parameter at immature stage and dry stage was negatively and significantly correlated with lutein, zeaxanthin, $\beta$-carotene and total carotenoid content, indicating that color parameter can be used as an indirect selection criterion for these traits.
\end{abstract}

Keywords: Maize; breeding; population improvement; orange kernel color; carotenoids.

Abbreviations: B_ß-carotene, DA_Days to anthesis, DM_Downy mildew, ED_Ear diameter, EL_Ear length, HEW_Husked ear weight, LT_Lutein, NCLB_Northern Corn Leaf Blight, PH_Plant height, TC_Total carotenoids, TY_Total yield, Z_Zeaxanthin

\section{Introduction}

Waxy corn is an important vegetable crop in Asian countries. It is consumed as boiled or streamed vegetable and popular among people in these countries because of its eating quality due to glutinous starch in endosperm characterized by high amylopectin. The colors of waxy corn kernels can be white, white-cream, yellow, purple and black. The waxy corn kernels with different colors have shown varying carotenoids, anthocyanins, phenolics and antioxidant activities (Hu and Xu, 2011; Khampas et al., 2013; Harakotr et al., 2015; Simla et al., 2016).

However, commercial varieties with white or white-cream kernel colors are more popular than those with other colors. In contrast to waxy corn, field corn with yellow or orange endosperm has been recognized as the major source of carotenoids (provitamin A) (Ibrahim and Juvik, 2009; Yang and Zhai, 2010; Žilić et al., 2012; Hwang et al., 2016). Moreover, sweet corn is also a major source of lutein, zeaxanthin and other carotenoids (Hart and Scott, 1995; Scott and Eldridge, 2005).
Carotenoids are red, yellow and orange plant pigments that can be classified into xanthophylls (lutein, zeaxanthin, and $\beta$ cryptoxanthin) and carotene ( $\beta$-carotene, and $\alpha$-carotene). Carotenoids are antioxidants that are beneficial to human health (Palozza and Krinsky, 1992) by maintaining eye health (Ma and Lin, 2010) and reducing the risk of cancer (Andlauer and Furst, 1999), diabetes (Zhang et al., 1992) and atherosclerosis (Dwyer et al., 2001). Lutein and zeaxanthin are major carotenoids found in corn kernels (Berardo et al., 2004; Egesel et al., 2003) and known as biologically-active substances of natural origin that prevent age-related macular degeneration (Bone and Landrum, 1992; Snodderly, 1995; McDermott, 2000; Mozaffarieh et al., 2003; Mares et al., 2006). Improvement of carotenoids in waxy corn kernels would add more beneficial values to waxy corn as these phytochemicals are useful to human health. However, the progress of waxy corn breeding for high carotenoids may depend on genetic variation for these traits and appropriate selection methods. 
The heritability values for provitamin A carotenoids in field corn were moderate to high, indicating that selection for carotenoids can be effective in early generations (Suwarno et al., 2014) and improvement of this trait by recurrent selection is possible (Senete et al., 2011). In temperate corn, genotype by environment interaction for carotenoids was not significant (Quakenbush et al., 1966). Provitamin A carotenoids, lutein and zeaxanthin can be increased by using S1 recurrent selection in three diverse maize populations and increases in these phytochemicals were associated with the increase in grain yield in one population and the reduction in grain yield in two populations (Dhliwayo et al., 2014). However, the information on genetic or population improvement of waxy corn for high carotenoids has been limited. Furthermore, improvement of carotenoids in endosperm of waxy corn requires the effective screening techniques. High performance liquid chromatography (HPLC) is commonly used for determination of carotenoids because the method provides the accurate results. Although the method is accurate, it is time-consuming, expensive and not practical in routine work of breeding programs for selecting high carotenoid progenies from the large populations. Color parameters have been suggested as an alternative selection method for high carotenoids (Mcguire, 1992; Hyman et al., 2004; Kljak and Grbe, 2014) and anthocyanin (Harakotr et al., 2015) in kernels in large corn populations. Although the method is simpler than other methods, it is not reliable for selection of high provitamin A in corn (Muthusamy et al., 2015). The information on the relationship between color parameters and carotenoids in waxy corn population is still lacking. The objectives of this study were to evaluate the improved populations of waxy corn that were subjected to two cycles of simple recurrent selection for yields, lutein, zeaxanthin, $\beta$-carotene and total carotenoids and to investigate the correlations between color parameters and carotenoids in waxy corn kernels at two growth stages. The information obtained in this study will be useful for waxy corn breeding to increase carotenoids, and the improved populations can be used as germplasm sources for developing new elite parental lines and hybrid varieties.

\section{Results and Discussion}

\section{Effect of location, cycle and their interactions}

Locations (L) were significantly different for most characters except for days to anthesis, lutein+zeaxanthin $+\beta$-carotene and color parameter $\left(\mathrm{h}^{\circ}\right)$ (Table 1$)$. Significant differences among cycles $(C)$ were found for most characters except for plant height. Cycle $\times$ location interactions $(\mathrm{CL})$ were not significant for total yield, husked ear weight, ear length, ear diameter, plant height and $h^{\circ}$. Location had moderate to large contribution to total yield (77.8\%), husked ear weight (53.4\%), ear length $(66.5 \%)$, ear diameter $(37.1 \%)$ and plant height (93.6\%) (Table 1). Soil parameters may not be the cause of differences because soil management practices were optimum in both locations. Variations due to location might be caused by differences in air temperatures between the locations. Khon Kaen location had lower average temperature $\left(24.5 \mathrm{C}^{\circ}\right)$ than Uthai Thani $\left(27.1 \mathrm{C}^{\circ}\right)$. In previous investigations, high temperature reduced the duration of growth, whole plant dry matter and grain yield of maize despite high levels of radiation (Badu-Apraku et al., 1983;
Muchow et al., 1989). The contributions to variations due to location were small for lutein (15.5\%), zeaxanthin (9.7\%), $\beta$ carotene (10.6\%) and total carotenoids (3.6\%) (Table 1). In previous study, variations in lutein, zeaxanthin, $\beta$-carotene, $\beta$-cryptoxanthin, $\alpha$-carotene and total pro-vitamin A content due to genotype were higher than those due to genotype by location interaction (Menkir et al., 2008). The results in this study were in agreement with those in previous study. In addition, Menkir and Maziya-Dixon (2004) reported that $\beta$ carotene was more strongly influenced by genotype than by environment but grain yield and other agronomic traits were influenced by both genotype and environment. Low environmental effect on these traits indicates that the traits are stable across environments and evaluation under few environments is sufficient to identify superior genotypes.

The contributions to variations due to selection cycle were low to moderate for yield, yield components and agronomic traits, ranging from 0.2 to $47.4 \%$ (Table 1 ), but they were moderate to high for lutein, zeaxanthin, $\beta$-carotene and total carotenoids, indicating that response to simple recurrent selection for carotenoids was higher than for other traits. Further selection for more cycles should increase carotenoids. The contributions to variations due to $\mathrm{CL}$ interaction were low to moderate for carotenoids, ranging from 8.5 to $26.4 \%$ (Table 1 ). In tropical field corn, the contribution to variation in carotenoids by genotype by environment interaction was small (Menkir et al., 2008). In temperate field corn, genotype by environment interaction had low effect on carotenoids (Quakenbush et al., 1966). The results in this study support previous findings and also add new information for waxy corn. The results indicated that evaluation in few major target areas would be sufficient to identify superior genotypes with high carotenoids.

\section{Recurrent selection}

Recurrent selection is an important breeding method and an alternative breeding strategy to improve the populations of crop plants mainly in cross-pollinated species (Vasal et al., 2004). This selection method can accumulate desirable genes or target phenotypes and promote recombination to create new allelic combinations for genetic improvement within the population (Sprague and Eberhart, 1977; Hallauer et al., 1988). Moreover, recurrent selection method can be used to improve germplasm sources, develop openpollinated varieties (OPV) and extract inbred lines for hybrid development. In maize, recurrent selection can be used to improve yield, provitamin A carotenoids, lutein, zeaxanthin (Dhliwayo et al., 2014), oil content, grain physical properties (Preciado-Ortiz et al., 2013), resistance to European corn borer and Diplodia (Diplodia maydis [Berkeley] Saccardo) stalk rot (Nyhus et al., 1988), resistance to downy mildew (DM) infection (Ajala et al., 2003), resistance to Fusarium ear rot and resistance to lodging (Horne et al., 2016). In waxy corn, modified mass selection has been used for improvement of prolificacy (Kesornkeaw et al., 2009), ear length (Senamontry et al., 2013) yield and maturity (Hussanun et al., 2014). Modified mass selection has been used for improvement of qualitative traits as selection is based on female plants.

In this study, simple recurrent selection successfully improved total yield (23.2\%), husked ear weight(15.0\%), ear 
Table 1. Mean squares for total yield (TY), husked ear weight (HEW), ear length (EL), ear diameter (ED), plant height (PH), days to anthesis (DA), lutein (LT), zeaxanthin (Z), $\beta$-carotene (B), $L T+Z+B$ and total carotenoids (TC).

\begin{tabular}{|c|c|c|c|c|c|c|c|}
\hline Source & DF & TY & HEW & $\mathrm{EL}$ & ED & $\mathrm{PH}$ & $\mathrm{DA}$ \\
\hline $\mathrm{L}$ & 1 & $\begin{array}{l}59.0 * * \\
(77.8)\end{array}$ & $\begin{array}{c}6,767^{* *} \\
(53.4)\end{array}$ & $\begin{array}{l}23.0^{* *} \\
(66.5)\end{array}$ & $\begin{array}{l}0.48 * * \\
(37.1)\end{array}$ & $\begin{array}{c}7,884 * * \\
(93.6)\end{array}$ & $\begin{array}{l}1.5 \mathrm{~ns} \\
(4.7)\end{array}$ \\
\hline $\mathrm{R} / \mathrm{L}(\mathrm{a})$ & 6 & 4.6 & 206 & 0.3 & 0.03 & 64 & 0.3 \\
\hline C & 2 & $\begin{array}{l}6.7^{* *} \\
(8.9)\end{array}$ & $\begin{array}{c}1,103^{* *} \\
(17.4)\end{array}$ & $\begin{array}{l}2.9 * * \\
(16.7)\end{array}$ & $\begin{array}{l}0.23 * * \\
(35.9)\end{array}$ & $\begin{array}{l}7 \mathrm{~ns} \\
(0.2)\end{array}$ & $\begin{array}{l}7.5^{* *} \\
(47.4)\end{array}$ \\
\hline $\mathrm{CL}$ & 2 & $\begin{array}{l}1.3 n s \\
(1.8)\end{array}$ & $\begin{array}{c}482 \mathrm{~ns} \\
(7.6)\end{array}$ & $\begin{array}{l}0.1 \mathrm{~ns} \\
(0.6)\end{array}$ & $\begin{array}{c}0.00 \mathrm{~ns} \\
(0.1)\end{array}$ & $\begin{array}{l}26 n s \\
(0.6)\end{array}$ & $\begin{array}{c}3.4^{*} \\
(21.2)\end{array}$ \\
\hline Error (b) & 12 & 4.0 & 125 & 0.3 & 0.02 & 7 & 0.6 \\
\hline C.V. (a)(\%) & & 14 & 8.8 & 2.9 & 3.8 & 3.5 & 1.1 \\
\hline C.V. (b)(\%) & & 9.1 & 6.8 & 3.4 & 3.0 & 1.2 & 1.6 \\
\hline & & $\mathrm{LT}$ & Z & $\mathrm{B}$ & $L T+Z+B$ & TC & $\mathrm{h}^{\circ}$ \\
\hline$L$ & 1 & $\begin{array}{c}18.2 * * \\
(15.5)\end{array}$ & $\begin{array}{c}3.4^{* *} \\
(9.7)\end{array}$ & $\begin{array}{l}1.87^{* *} \\
(10.6)\end{array}$ & $\begin{array}{l}1.0 n s \\
(0.4)\end{array}$ & $\begin{array}{l}6.6^{*} \\
(3.6)\end{array}$ & $\begin{array}{l}2.5 \mathrm{~ns} \\
(5.5)\end{array}$ \\
\hline R./L (a) & 6 & 0.6 & 0.2 & 0.03 & 0.5 & 0.8 & 0.5 \\
\hline $\mathrm{C}$ & 2 & $\begin{array}{c}39.8^{* *} \\
(68.0)\end{array}$ & $\begin{array}{l}9.8^{* *} \\
(56.2)\end{array}$ & $\begin{array}{c}5.24^{* *} \\
(59.6)\end{array}$ & $\begin{array}{c}121.3^{* *} \\
(91.2)\end{array}$ & $\begin{array}{l}57.7 * * \\
(62.6)\end{array}$ & $\begin{array}{l}17.4^{* *} \\
(75.5)\end{array}$ \\
\hline $\mathrm{CL}$ & 2 & $\begin{array}{c}5.0^{* *} \\
(8.5)\end{array}$ & $\begin{array}{l}4.1^{* *} \\
(23.5)\end{array}$ & $\begin{array}{l}2.41 * * \\
(27.4)\end{array}$ & $\begin{array}{c}6.4^{* *} \\
(4.8)\end{array}$ & $\begin{array}{l}20.2^{* *} \\
(21.9)\end{array}$ & $\begin{array}{l}0.1 \mathrm{~ns} \\
(0.5)\end{array}$ \\
\hline Error (b) & 12 & 0.5 & 0.2 & 0.02 & 0.5 & 1.5 & 0.5 \\
\hline C.V. (a)(\%) & & 17.9 & 13.2 & 5.9 & 6.7 & 6.5 & 0.9 \\
\hline C.V. (b)(\%) & & 15.1 & 14.3 & 4.2 & 6.8 & 8.9 & 0.9 \\
\hline
\end{tabular}

Table 2. Total yield (TY), husked ear weight (HEW), ear length (EL), ear diameter (ED), plant height (PH), days to anthesis (DA) of improved populations and check varieties at fresh stage across two locations in Thailand.

\begin{tabular}{|c|c|c|c|c|c|c|}
\hline \multirow[t]{2}{*}{ Cycles } & \multirow{2}{*}{$\begin{array}{l}\text { Tones/ha } \\
\text { TY }\end{array}$} & \multirow{2}{*}{$\begin{array}{l}\text { g/ear } \\
\text { HEW }\end{array}$} & \multicolumn{3}{|c|}{$\mathrm{cm}$} & \multirow[b]{2}{*}{ DA } \\
\hline & & & $\mathrm{EL}$ & ED & $\mathrm{PH}$ & \\
\hline $\mathrm{CO}$ & $5.6 \mathrm{~b}$ & $153.8 \mathrm{~b}$ & $16.7 \mathrm{~b}$ & $4.1 \mathrm{~b}$ & 227.0 & $48.0 \mathrm{a}$ \\
\hline C1 & $6.5 \mathrm{a}$ & $161.8 \mathrm{~b}$ & $17.4 \mathrm{a}$ & $4.3 \mathrm{a}$ & 227.4 & $46.6 \mathrm{~b}$ \\
\hline $\mathrm{C} 2$ & $6.9 \mathrm{a}$ & $176.9 \mathrm{a}$ & $17.9 \mathrm{a}$ & $4.4 \mathrm{a}$ & 228.8 & $46.1 \mathrm{~b}$ \\
\hline b-value & 0.7 & 11.6 & 0.6 & 0.2 & 0.9 & -0.9 \\
\hline Percentage increase & 23.2 & 15.0 & 7.2 & 7.3 & - & -3.9 \\
\hline \multicolumn{7}{|l|}{ Check varieties } \\
\hline Sugar75 & 7.5 & 220.9 & 18.7 & 4.5 & 201.3 & 46.3 \\
\hline PAC339 & 11.1 & 181.1 & 17.8 & 4.1 & 215.9 & 47.3 \\
\hline
\end{tabular}

Mean in the same letter within the same column are not significant $(P \leq 0.05)$ determined by LSD. Percent increase from C0 to C2.

Table 3. Lutein (LT), zeaxanthin (Z), $\beta$-carotene (B), total carotenoids (TC) and $h^{\circ}$ of improved populations and check varieties at fresh stage across two locations in Thailand.

\begin{tabular}{|c|c|c|c|c|c|c|c|c|c|c|c|}
\hline \multirow{3}{*}{ Cycles } & \multicolumn{10}{|c|}{$\mu / g$ fresh weight } & \multirow{3}{*}{$h^{\circ}$} \\
\hline & \multicolumn{2}{|l|}{ LT } & \multicolumn{2}{|l|}{$Z$} & \multicolumn{2}{|c|}{ B } & \multicolumn{2}{|l|}{$L T+Z+B$} & \multicolumn{2}{|l|}{$\mathrm{TC}$} & \\
\hline & KK & UT & KK & UT & KK & UT & KK & UT & KK & UT & \\
\hline $\mathrm{CO}$ & $1.8 \mathrm{c}$ & $2.9 \mathrm{c}$ & $1.8 \mathrm{c}$ & $2.2 \mathrm{~b}$ & $2.6 \mathrm{~b}$ & $2.7 \mathrm{~b}$ & $6.2 c$ & $7.7 \mathrm{c}$ & 13.2 & $9.2 \mathrm{c}$ & $79.3 \mathrm{a}$ \\
\hline $\mathrm{C} 1$ & $4.0 \mathrm{~b}$ & $4.6 \mathrm{~b}$ & $5.1 \mathrm{a}$ & $2.8 \mathrm{~b}$ & $2.7 \mathrm{~b}$ & $2.8 \mathrm{~b}$ & $11.7 \mathrm{~b}$ & $10.1 \mathrm{~b}$ & 13.6 & $12.2 \mathrm{~b}$ & $78.5 \mathrm{~b}$ \\
\hline $\mathrm{C2}$ & $5.0 \mathrm{a}$ & $8.6 \mathrm{a}$ & $4.0 \mathrm{~b}$ & $3.7 \mathrm{a}$ & $5.0 \mathrm{a}$ & $3.2 \mathrm{a}$ & $14.0 \mathrm{a}$ & $15.4 \mathrm{a}$ & 15.3 & $17.6 \mathrm{a}$ & $76.5 \mathrm{c}$ \\
\hline F-test & $* *$ & $* *$ & $* *$ & $* *$ & $* *$ & $* *$ & $* *$ & $* *$ & ns & $* *$ & $* *$ \\
\hline C.V. (\%) & 9.9 & 16.6 & 15.4 & 12.1 & 4.5 & 3.7 & 5.7 & 7.7 & 9.4 & 8.3 & 0.9 \\
\hline $\mathrm{b}$ & 1.6 & 2.9 & 1.1 & 0.8 & 1.2 & 0.3 & 3.9 & 3.9 & 1.1 & 4.2 & -1.4 \\
\hline Percentage increase & 177.8 & 196.6 & 122.2 & 68.2 & 92.3 & 18.5 & 125.8 & 100.0 & - & 91.3 & -3.5 \\
\hline \multicolumn{12}{|l|}{ Check varieties } \\
\hline Sugar75 & 2.0 & 1.6 & 5.3 & 3.5 & 1.9 & 2.0 & 9.2 & 7.1 & 10.1 & 6.9 & 80.0 \\
\hline PAC339 & 3.5 & 2.9 & 11.8 & 6.9 & 2.6 & 2.7 & 17.9 & 12.5 & 21.5 & 16.5 & 75.2 \\
\hline
\end{tabular}

Mean in the same letter within the same column are not significant $(p \leq 0.05)$ determined by LSD. Percent increase from CO to C1. ${ }^{b}$ KK is Khon Kaen province and UT is Uthai Thani province ns non-significant ${ }^{*}$ significant at the 0.05 . level $* *_{\text {Significant at the } 0.01 \text { level. }}$ 
Table 4. Correlations among color parameter $\left(h^{\circ}\right)$ at fresh and dry stage with lutein (LT), zeaxanthin (Z), $\beta$-carotene (B), $L T+Z+B$ and total carotenoids (TC) at fresh stage $(n=25)$.

\begin{tabular}{|c|c|c|c|c|c|c|}
\hline & \multicolumn{2}{|l|}{$\mathrm{h}^{0}$} & \multirow[t]{2}{*}{ LT } & \multirow[t]{2}{*}{$Z$} & \multirow[t]{2}{*}{$B$} & \multirow[t]{2}{*}{$\mathrm{LT}+\mathrm{Z}+\mathrm{B}$} \\
\hline & Fresh & Dry & & & & \\
\hline LT & $-0.83^{* *}$ & $-0.61^{* *}$ & & & & \\
\hline Z & $-0.73^{* *}$ & $-0.94 * *$ & $0.38 *$ & & & \\
\hline B & $-0.78^{* *}$ & $-0.43^{*}$ & $0.88^{* *}$ & 0.22 & & \\
\hline$L T+Z+B$ & $-0.88^{* *}$ & $-0.80 * *$ & $0.94 * *$ & $0.68 * *$ & $0.79 * *$ & \\
\hline $\mathrm{TC}$ & $-0.86^{* *}$ & $-0.59 * *$ & $0.70 * *$ & $0.65 * *$ & $0.67 * *$ & $0.80 * *$ \\
\hline
\end{tabular}

*Significant at the 0.05 level. ${ }^{* *}$ Significant at the 0.01 level.

Table 5. Corn populations used for forming a base population in this research.

\begin{tabular}{|c|c|c|c|c|c|}
\hline Names & Types & Corn types & Kernel color & Details & Sources \\
\hline KND & Population & Waxy corn & Purple & $\begin{array}{l}\text { Susceptible to DM, rust and } \\
\text { NCLB diseases }\end{array}$ & $\begin{array}{l}\text { Khon Kaen } \\
\text { University }\end{array}$ \\
\hline Ki56 & Inbred & Field corn & Orange & Resistance to DM disease & $\begin{array}{l}\text { National Research } \\
\text { Centre of Millet } \\
\text { and Corn }\end{array}$ \\
\hline NS3 & Hybrid & Field corn & Orange & $\begin{array}{l}\text { Resistance to DM and rust } \\
\text { diseases } \\
\text { Drought tolerance }\end{array}$ & $\begin{array}{l}\text { Nakhon Sawan } \\
\text { Field Crops } \\
\text { Research Center }\end{array}$ \\
\hline NSX042202 & Hybrid & Field corn & Orange & $\begin{array}{l}\text { Resistance to DM and rust } \\
\text { diseases } \\
\text { Drought tolerance }\end{array}$ & $\begin{array}{l}\text { Nakhon Sawan } \\
\text { Field Crops } \\
\text { Research Center }\end{array}$ \\
\hline Hibrix53 & Hybrid & $\begin{array}{l}\text { Super } \\
\text { sweet corn }\end{array}$ & Yellow & Resistance to NCLB disease & $\begin{array}{l}\text { Pacific Seed } \\
\text { Company }\end{array}$ \\
\hline
\end{tabular}

DM downy mildew, NCLB Northern Corn Leaf Blight.

length $(7.2 \%)$, ear diameter (7.3\%) and days to anthesis (3.9\%) (Table 2). The results indicated that simple recurrent selection is suitable for improving these traits in waxy corn. In previous study, yield and carotenoids could be improved simultaneously by S1 recurrent selection (Dhliwayo et al., 2014). The method is achieved by self-pollination of selected plants and S1 seeds are combined for the next generation. In this study; however, percent increases in carotenoids were much higher than in yield, indicating the best response to selection for this trait. Although simple recurrent selection could improve yield, the yield of improved population was still lower than those of the check varieties, and the improved population had shorter plants than did the check varieties. The differences between the improved population and hybrid checks would be due to the types of varieties.

Simple recurrent selection based on visual observation of the traits (without complex laboratory) could improve lutein, zeaxanthin, $\beta$-carotene, lutein+zeaxanthin $+\beta$-carotene and total carotenoids at most locations except for total carotenoids at Khon Kaen location, but it significantly reduced color parameter $\left(\mathrm{h}^{\circ}\right)$ (Table 3 ). Cycle 2 had the highest lutein, zeaxanthin, $\beta$-carotene, lutein + zeaxanthin $+\beta$ carotene and total carotenoids at most locations except for zeaxanthin at Khon Kaen location, in which cycle 1 was highest. The positive responses would be due to sufficient genetic variations in pro-vitamin A, carotenoids (Suwarno et al., 2014; Senete et al., 2011), lutein, zeaxanthin and $\beta$ carotene (Muthusamy et al., 2016). Recurrent selection could increase carotenoids in maize (Senete et al., 2011). Genetic control of carotenoids may not be so complex, and improvement of this trait through simple recurrent selection can be successful at early cycles of selection.

The improved population from simple recurrent selection for two cycles had higher lutein, $\beta$-carotene and total carotenoids than sweet corn variety (Su75), and improved population and Su75 had similar zeaxanthin. Field corn (PAC339) at Knon Kaen location had higher zeaxanthin and total carotenoids content than the improved population. However, the improved population had higher lutein, $\beta$ carotene than field corn. Although the improved population of waxy corn was not higher than the check varieties for carotenoids, white waxy can be converted to yellow waxy corn with high carotenoids by recombination followed by few cycles of simple recurrent selection.

\section{Relationship between color parameter and carotenoids}

The simple, rapid and inexpensive techniques for selection of high carotenoids in corn populations are required for effective breeding programs. In general, color parameter $\left(h^{\circ}\right)$ was negatively and significantly correlated with $L T, Z, B$, $\mathrm{LT}+\mathrm{Z}+\mathrm{B}$ and $\mathrm{TC}$ at immature stage and the correlation coefficients ranged from -0.73 to -0.88 at $P \leq 0.01$ (Table 4). Likewise, $h^{0}$ at dry stage was also negatively correlated with lutein $\left(-0.66^{* *}\right)$, zeaxanthin $(-0.94 * *), \beta$-carotene $\left(-0.43^{*}\right)$, lutein+zeaxanthin $+\beta$-carotene $(-0.80 * *)$ and total carotenoids $\left(-0.59^{* *}\right)$. In other works, color parameter was negatively correlated with carotenoid content in field corn (Mcguire, 1992; Hyman et al., 2004; Kljak and Grbe, 2014), anthocyanins in waxy corn (Harakotr et al., 2015), total phenolics, carotenoids and flavonoids and antioxidant activity in wheat (Ma et al., 2014).

Selection against color parameters in this waxy corn population would result in the increase in carotenoid content and the method can be used for screening of corn populations with a large number of plants. The negative association of these characters would be possibly due to high color parameter of waxy corn parent and low color parameter of corn parents of carotenoid source. 
Selection for high carotenoids in waxy corn has been carried out at mature stage, but waxy corn is mostly utilized as a vegetable at immature stage. The information on the correlation between carotenoids at immature stage and color parameter at mature stage would be useful for waxy corn breeding for high carotenoids because color parameter will be used as a non-destructive surrogate trait for carotenoids. In this study, most correlation coefficients among lutein, zeaxanthin, $\beta$-carotene, lutein+zeaxanthin $+\beta$ carotene and total carotenoids at immature stage were positive and significant, ranging from 0.67 to 0.94 at $P \leq 0.01$ except for the correlation coefficients between zeaxanthin and lutein and between zeaxanthin and $\beta$-carotene. In previous studies in field maize, zeaxanthin was positively and significantly correlated with lutein (Muthusamy et al., 2015; Muthusamy et al., 2016). Different genetic materials might express the different correlations among these traits. In general, the results in this study supported that selection for high total carotenoid content resulted in the increases in lutein, zeaxanthin and $\beta$-carotene in waxy corn.

\section{Materials and methods}

\section{Plant materials}

One corn population and four corn hybrids with differences in types of corn (waxy corn, sweet corn and field corn), kernel colors (orange, yellow and purple) and disease resistant levels (downy mildew, rust and northern corn leaf blight) were used for improvement of a base population of waxy corn (Table 5). KND is a waxy corn population with purple kernel or high anthocyanins from Khon Kaen University, Thailand. Ki56, NS3 and NSX 042202 are field corn hybrids with high carotenoids and pest resistance from the National Research Centre of Sorghum and Corn and the Nakhon Sawan Field Crops Research Center, Thailand. Hibrix53 is a sweet corn hybrid with resistance to Northern Corn Leaf Blight disease from Pacific Seed Company, Thailand.

\section{Development of base population and population improvement}

KND was used as a female parent for crosses with Ki56, NS3, NSX042202 and Hibrix53, and it was also used as male parent for reciprocals in 2012. Therefore, there were four crosses and four reciprocals altogether. The crosses and reciprocals were combined to form a base population by random mating for two seasons without selection in 2013 and 2014. The new population was ready for population improvement through simple recurrent selection.

Simple recurrent selection was carried out for four seasons in 2014 to 2016. There were two seasons for each cycle consisting of selection of best plants and random mating of selected seeds to form a new cycle. Selection for two cycles was completed in a breeding nursery at the Vegetable Farm, Faculty of Agriculture, Khon Kaen University, Thailand.

For the first season, the selected plants for good stand ability, stay green and disease free were self-pollinated by hand. The plants (10\%) were harvested and the seeds from long ears with good husk cover, short to moderate anthesis, waxy kernels and orange or deep yellow kernels were bulked and planted in the next season (COS1 seed). For the second season, COS1 was crossed within population to generate cycle1 or $\mathrm{C} 1$ population. The second cycle was completed in 2016 and three populations including initial population (CO), and two improved populations ( $\mathrm{C} 1$ and $\mathrm{C} 2$ ) were available for evaluation.

\section{Field evaluation}

C0, improved populations ( $\mathrm{C} 1$ and $\mathrm{C} 2$ ), one commercial variety of field corn (Pacific339) and one variety of super sweet corn (Sugar75) were evaluated in a randomized complete block design with four replications at two locations in Thailand (Khon Kaen; KK and Uthai Thani; UT) in the rainy season 2016 (May to September 2016).

The soil at Khon Kaen location $\left(16^{\circ} 28^{\prime} 11.24^{\prime \prime} \mathrm{N} 102^{\circ} 48^{\prime} 49.46\right.$ $\mathrm{E} ; 200 \mathrm{msl}$ ) was sandy, low in $\mathrm{pH}$ (6.4) and low in organic matter $(0.7 \%)$, whereas the soil at Uthai Thani location $\left(15^{\circ} 22^{\prime} 57.77^{\prime \prime} \mathrm{N}\right.$ E $\left.100^{\circ} 4^{\prime} 42.54^{\prime \prime} \mathrm{E} ; 20 \mathrm{msl}\right)$ was loamy sand, low in $\mathrm{pH}(5.5)$ and low in organic matter (1.4\%). Both locations had similar rainfall and solar radiation at vegetative period (0-60 days), but Khon Kaen location had lower averaged temperature $\left(24.1 \mathrm{C}^{\circ}\right)$ than did Uthai Thani location $\left(27.5 \mathrm{C}^{\circ}\right)$.

Each plot consisted of 6 rows with $5 \mathrm{~m}$ long and a spacing of $0.8 \mathrm{~m}$ between rows and $0.25 \mathrm{~m}$ between plants within rows. Soil preparation, planting and other agronomic practices were carried out according to the recommendations for commercial production of corn in Thailand (Department of Agriculture, 2004). Sib-pollination was done for each population to prevent contamination from the other populations. Data were recorded for yield, yield components and agronomic traits.

\section{Sample preparation}

Five husked ears were collected in each plot at milky stage (20 days after anthesis) for chemical analysis. Kernel samples were removed from the cobs by a sharp knife, put in sealable plastic bags, and stored in liquid nitrogen at $-20{ }^{\circ} \mathrm{C}$ until analysis.

Five husked ears were also collected in each plot at physiological maturity stage ( 30 days after anthesis) and the ear samples were oven-dried at $40{ }^{\circ} \mathrm{C}$. The kernel samples were removed from the cobs by hands, milled into fine powder by an electric grinder and stored at $-20{ }^{\circ} \mathrm{C}$ until analysis.

\section{Sample extraction and determination of total carotenoids}

Sample extraction and determination of total carotenoid content were carried out using UV-vis spectrophotometer as described by Schaub et al., (2004). The supernatant from extract solution was used for determining total carotenoids content at $450 \mathrm{~nm}$ wavelength. The total carotenoids content was expressed as microgram per gram sample $(\mu \mathrm{g} / \mathrm{g}$ sample), and it was calculated according to the following formula;

Carotenoid content $(\mu \mathrm{g})=\frac{A \times V(\mathrm{ml}) \times 10^{4}}{A_{1 \mathrm{~cm}}^{1 \%} \times P(g)}$,

Where; $\mathrm{A}=$ Absorbance; $\mathrm{V}=$ Total extract volume; $\mathrm{P}=$ sample weight $A_{1 \mathrm{~cm}}^{1 \%}=2500(\beta$-carotene Extinction Coefficient in petroleum ether). 


\section{HPLC-PDA analysis of carotenoids}

The HPLC-PDA analysis was slightly modified, as performed by the method described previously (Gupta et al., 2015). The stock solutions of lutein and zeaxanthin were prepared in 0.1 $\mathrm{mg} / \mathrm{mL}$ of ethanol, and the stock solution of $\beta$-carotene was prepared in hexane of $0.1 \mathrm{mg} / \mathrm{mL}$. The exact concentration of each stock solution was determined by spectrophotometry using absorption coefficient A (1\%, 1 $\mathrm{cm})$. After determination of the concentration, the standards were evaporated under nitrogen and solubilized in methanol/MTBE $(25 / 75, \mathrm{v} / \mathrm{v})$ to obtain a final concentration of $5 \mu \mathrm{g} / \mathrm{mL}$, which was further used for HPLC analysis.

Carotenoids were analyzed by reversed phase HPLC using HPLC model LC 20A (Shimadzu, Japan) equipped with a quaternary pump, an online degasser, a column oven controller and a photodiode array detector (PDA). Carotenoids were separated on a reversed-phase C30, $3 \mu \mathrm{m}$ column $(250 \times 4.6 \mathrm{~mm})$ coupled to a $20 \times 4.6 \mathrm{~mm} \mathrm{C30}$ guard column (YMC Co., Kyoto, Japan) using mobile phases consisting of (A) methanol/water (98:2, v/v), (B) methanol/water $(95: 5, \mathrm{v} / \mathrm{v})$ and $(\mathrm{C})$ tert-methyl butyl ether. The gradient elution used with this column was $80 \% \mathrm{~A}, 20 \%$ $\mathrm{C}$ at $0 \mathrm{~min}$, followed by linear gradient to $60 \% \mathrm{~A}, 40 \% \mathrm{C}$ to $2.00 \mathrm{~min}$ at a flow rate of $1.4 \mathrm{~mL} / \mathrm{min}$. The $2.01 \mathrm{~min}$ flow rate was changed to $1.00 \mathrm{~mL} / \mathrm{min}$ and the gradient was changed to $60 \%$ B, $40 \%$ C followed by a linear gradient to $0 \%$ B, $100 \%$ $\mathrm{C}$ by $12 \mathrm{~min}$ and was returned to the initial condition by $13.00 \mathrm{~min}$. A re-equilibration $(7.00 \mathrm{~min})$ was carried out at the initial concentration of $80 \%$ A, $20 \%$ C. Column temperature was maintained at $20{ }^{\circ} \mathrm{C}$. The eluting peaks were monitored at a range of 350 to $600 \mathrm{~nm}$ using PDA. Quantification was performed using Xcalibur software (version 2.2) by comparing peak area with standard (Gupta et al. 2015).

Five $\mathrm{mL}$ of supernatant from extracted sample were dried by nitrogen evaporation and re-dissolved in $1 \mathrm{~mL}$ of methanol/MTBE $(25 / 75, \mathrm{v} / \mathrm{v})$ prior to analysis. A final volume of $20 \mu \mathrm{L}$ was used for injection into HPLC. Peaks were identified by comparing the retention times and UV-Vis spectral data with those of the corresponding standards. Quantity of each analyzed sample was computed from the calibration curve of the corresponding standard. Six-point external standard curves $\left(R^{2}=0.998\right)$ were constructed for the standard mix. Carotenoid concentrations were then calculated using a linear regression as follows;

$y=a x+b$,

Where; $y=$ concentration and $x=$ area of the six-point standard curve. The regression equation and correlation coefficient $\left(R^{2}\right)$ were obtained using Microsoft ${ }^{\circledR}$ Excel 2016.

\section{Color measurement}

Color values were determined from five ears in each plot by HunterLab miniscan EZ colorimeter (Mod. MSEZ-4500L, Hunter Associates Laboratory Inc., VA, USA). The color values were averaged from three positions of the ears at the top middle and bottom. The color parameter was expressed in hue $\left(\mathrm{h}^{\circ}\right)$. The $\mathrm{h}^{\circ}$ was expressed in degree range from $0^{\circ}$ to $360^{\circ}\left(0^{\circ}=\right.$ red, $90^{\circ}=$ yellow, $180^{\circ}=$ green and $270^{\circ}=$ blue $)$ (Mcguire, 1992).

\section{Data analysis}

Analysis of variance for each location was performed for all parameters under study. Error variances were tested for variance homogeneity and the difference of error variances which was lower than three folds was considered homogenous. The data of parameters with homogenous error variance were combined in combined analysis of variance of two locations and the least significant difference (LSD) test was used to compare means (Gomez and Gomez, 1984). Pearson correlation test was conducted to determine the correlation between color parameters and carotenoids.

\section{Conclusion}

Simple recurrent selection for two cycles could successfully improve total yield, husked ear weight, ear length and ear diameter of orange waxy corn population. The method of simple recurrent selection could be used for improving lutein, zeaxanthin, $\beta$-carotene and total carotenoids in this waxy corn population. The responses to selection indicate that further improvement of these traits through simple recurrent selection is possible. This improved population can be used as a source of carotenoids in waxy corn breeding programs for hybrid development or released as an open pollinated variety. As the response to selection was negative and significant and the correlation coefficients between lutein, zeaxanthin, $\beta$-carotene and total carotenoids with color parameter $\left(\mathrm{h}^{\circ}\right)$ were also negative and significant, color parameter can be used as an indirect selection method for increasing lutein, zeaxanthin, $\beta$-carotene and total carotenoids in waxy corn at both immature stage and dry stage.

\section{Acknowledgements}

The authors thankfully acknowledge the Thailand Research Fund for providing financial support through the Senior Research Scholar Project of Prof. Dr. Sanun Jogloy (Project no. RTA 5880003), the National Science and Technology Development Agency, Thailand and the Plant Breeding Research Center for Sustainable Agriculture, Khon Kaen University. This work was extended to the Thailand Research Fund (Project code: IRG5780003), Khon Kaen University and the Faculty of Agriculture KKU for providing financial support for manuscript preparation activities.

\section{References}

Ajala SO, Kling JG, Kim SK, Obajimi AO (2003) Improvement of maize populations for resistance to downy mildew. Plant Breed. 122:328-333.

Andlauer W, Furst, P (1999) Does cereal reduce the risk of cancer? Cereal Foods World. 44: 76-78.

Badu-Apraku B, Hunter RB, Tollenaar M (1983) Effect of temperature during grain filling on whole plant and grain yield in maize (Zea mays L.). Can J Plant Sci. 63:357-363.

Berardo N, Brenna OV, Amato A, Valoti P, Pisacane V, Motto $M$ (2004) Carotenoids concentration among maize genotypes measured by near infrared reflectance spectroscopy (NIRS). Innov Food Sci Emerg Technol. 5:393398. 
Bone RA, Landrum JT (1992) Distribution of macular pigment components, zeaxanthin and lutein, in human retina. In: Packer L (ed) Methods in enzymology. Academic Press, San Diego.

Dwyer JH, Navab M, Dwyer KM, Hassan K, Sun P, Shircore A, Hama-Levy S, Hough G, Wang $X$, Drake T, Merz CNB, Fogelman AM (2001) Oxygenated carotenoid lutein and progression of early atherosclerosis: the Los Angeles atherosclerosis study. Circulation. 103:2922-2927.

Dhliwayo T, Palacios-Rojas N, Crossa J, Pixley KV (2014) Effects of S1 recurrent selection for provitamin a carotenoid content for three open-pollinated maize cultivars. Crop Sci. 54:2449-2460.

Egesel CO, Wong RJ, Rocheford TR (2003) Combining ability of maize hybrids for carotenoids and tocopherols. Crop Sci. 43:818-823.

Field Crop Research Institute, Department of Agriculture (2004) Academic Documents Maize. Department of Agriculture, Ministry of Agriculture, Thailand. (In Thai)

Gomaz KA, Gomez AA (1984) Statistical procedures for agricultural research. $2^{\text {ed }}$ edition. John Wiley \& Sons. Singapore.

Gupta P, Sreelakshmi Y, Sharma R (2015) A rapid and sensitive method for determination of carotenoids in plant tissues by high performance liquid chromatography. Plant Methods. 11:5.

Hallauer AR, Russell WA, Lamkey KR (1988) Corn breeding. In: Sprague GF, Dudley JW (eds) Corn and corn improvement. American Society of Agronomy, USA.

Harakotr B, Suriharn B, Scott MP, Lertrat K (2015) Genotypic variability in anthocyanins, total phenolics, and antioxidant activity among diverse waxy corn germplasm. Euphytica. 203:237-248.

Hart DJ, Scott KJ (1995) Development and evaluation of an HPLC method for the analysis of carotenoids in foods, and the measurement of the carotenoid content of vegetables and fruits commonly consumed in the UK. Food Chem. 54:101-111.

Horne DW, Eller MS, Holland JB (2016) Responses to recurrent index selection for reduced Fusarium ear rot and lodging and for increased yield in maize. Crop Sci. 56:8594.

Hussanun S, Suriharn B, Lertrat K (2014) Yield and early maturity response to four cycles of modified mass selection in purple waxy corn. Turk J Field Crops. 19:84-89.

Hwang T, Ndolo VU, Katundu M, Nyirenda B, Bezner-Kerr R, Arntfield S, Beta T (2016) Provitamin A potential of landrace orange maize variety (Zea mays L.) grown in different geographical locations of central Malawi. Food Chem. 196:1315-1324.

Hu Q, Xu J (2011) Profiles of carotenoids, anthocyanins, phenolics, and antioxidant activity of selected color waxy corn grains during maturation. J Agric Food Chem. 59:2026-2033.

Hyman JR, Gaus J, Foolad MR (2004) A rapid and accurate method for estimating tomato lycopene content by measuring chromaticity values of fruit purée. J Am Soc Hortic Sci. 129:717-23.

Ibrahim KE, Juvik JA (2002) Feasibility for improving phytonutrient content in vegetable crops using conventional breeding strategies; case study with carotenoids and tocopherols in sweet corn and broccoli. J Agric Food Chem. 57:4636-4644.
Kesornkeaw P, Lertrat K, Suriharn B (2009) Response to four cycles of mass selection for prolificacy at low and high population densities in small ear waxy corn. Asian J Plant Sci. 8:425-432.

Khampas S, Lertrat K, Lomthaisong K, Suriharn B (2013) Variability in phytochemicals and antioxidant activity in corn at immaturity and physiological maturity stages. Inter Food Res J. 20:3149-3157.

Kljak K, Grbesa D, Karolyi D (2014) Reflectance colorimetry as a simple method for estimating carotenoid content in maize grain. J Cereal Sci. 59:109-11.

Ma DY, Sun DX, Zuo Y, Wang CY, Zhu YJ, Guo TC (2014) Diversity of antioxidant content and its relationship to grain color and morphological characteristics in winter wheat grains. J Integr Agric. 13:1258-1267.

Ma L, Lin XM (2010) Effects of Lutein and Zeaxanthin on aspects of eye health. J Sci Food Agric. 90:2-12.

Mares JA, LaRowe TL, Snodderly DM, Moeller SM, Gruber MJ, Klein ML, Wooten BR, Johnson EJ, Chappell RJ (2006) Predictors of optical density of lutein and zeaxanthin in retinas of older women in the carotenoids in age related eye disease study, an ancillary study of the women's health institute. Am J Clin Nutr. 84:1107-1122.

McDermott JH (2000) Antioxidant nutrients: Current dietary recommendations and research update. J Am Pharm Assoc. 40:785-799.

Mcguire RG (1992) Reporting of objective color measurements. HortScience. 27:1254-1255.

Menkir A, Liu W, White WS, Maziya-Dixon B, Rocheford T (2008) Carotenoid diversity in tropical-adapted yellow maize inbred lines. Food Chem. 109:521-529.

Menkir A, Maziya-Dixon B (2004) Influence of genotype and environment on $ß$-carotene content on tropical yellow endosperm maize genotypes. Maydica. 49:313-318.

Mozaffarieh M, Sacu S, Wedrich A (2003) The role of the carotenoids, lutein and zeaxanthin, in protecting against age-related macular degeneration: a review based on controversial evidence. Nutr J. 11:20-28.

Muchow RC, Sinclair TR, Bennett JM (1989) Temperature and solar radiation effects on potential maize yield across locations. Agron J. 82:338-343.

Muthusamy V, Hossain F, Thirunavukkarasu N, Saha S, Agrawal PK, Guleria SK, Gupta HS (2015) Genetic variability and inter-relationship of kernel carotenoids among indigenous and exotic maize (Zea mays L.) inbreds. Cereal Res Commun. 43:567-578.

Muthusamy V, Hossain F, Thirunavukkarasu N, Saha S, Agrawal PK, Gupta HS (2016) Genetic analyses of kernel carotenoids in novel maize genotypes possessing rare allele of [beta]-carotene hydroxylase gene. Cereal Res Commun. 44:669-680.

Nyhus KA, Russell WA, Guthrie WD (1988) Response of two maize synthetics to recurrent selection for resistance to first-generation european corn borer (Lepidoptera: Pyralidae) and diplodia stalk rot. J Econ Entomol. 81:17921798.

Palozza P, Krinsky NI (1992) Antioxidant effects of carotenoids in vivo and in vitro: an overview. Methods Enzymol. 213:403-420.

Preciado-Ortiz RE, García-Lara S, Ortiz-Islas S, Ortega-Corona A, Serna-Saldivar SO (2013). Response of recurrent selection on yield, kernel oil content and fatty acid 
composition of subtropical maize populations. Field Crops Res. 142:27-35.

Quakenbush FW, Firch JG, Brunson AM, House LR (1966) Carotenoid, oil, and tocopherol content of corn inbred. Cereal Chem. 40:251-259.

Schaub P, Beyer P, Ismand S, Rosherford T (2004) Maize Quick Carotenoid Extraction Protocol. [2017-1013].

http://www.cropsci.uiuc.edu/faculty/rocheford/qu ick_carotenoid_analysis__protocol.pdf

Scott CE, Eldridge AL (2005) Comparison of carotenoid content in fresh, frozen and canned corn. J Food Comp Anal. 18:551-559.

Senamontry K, Lertrat K, Suriharn B (2013) Response to five cycles of modified mass selection for ear length in waxy corn. SABRAO J Breed Genet. 45:332-340.

Senete CT, Guimarães PEO, Paes MCD, Souza JC (2011) Diallel analysis of maize inbred lines for carotenoids and grain yield. Euphytica. 182:395-404.

Snodderly DM (1995) Evidence for protection against agerelated macular degeneration by carotenoids and antioxidant vitamins. Am J Clin Nutr. 62:1448S-1461S.

Sprague GF, Eberhart SA (1977) Corn breeding. In: Sprague GF (ed) Corn and corn improvement. American Society of Agronomy, USA.
Simla S, Boontang S, Harakotr B (2016) Anthocyanin content, total phenolic content, and antiradical capacity in different ear components of purple waxy corn at two maturation stages. Aust J Crop Sci. 10:675-682.

Suwarno WB, Pixley KV, Palacios-Rojas N, Kaeppler SM, Babu $\mathrm{R}$, (2014) Formation of heterotic groups and understanding genetic effects in a provitamin A biofortified maize breeding program. Crop Sci. 54:14-24.

Vasal SK, Singh NN, Dhillon BS, Patil SJ (2004) Population improvement strategies for crop improvement. In: Jain HK, Kharkwal MC (eds) Plant breeding mendelian to molecular approaches. Narosa Publishing House, New Delhi, India.

Yang Z, Zhai W (2010) Identification and antioxidant activity of anthocyanins extracted from the seed and cob of purple corn (Zea mays L.). Innov Food Sci Emerg Technol. 11:169176.

Zhang LX, Cooney RV, Bertram JS (1992) Carotenoids upregulate connexin43 gene expression independent of their provitamin A or antioxidant properties. Cancer Res. 52:5707-5712.

Žilić S, Serpen A, Akıllıoğlu G, Gökmen V, Vančetović J (2012) Phenolic compounds, carotenoids, anthocyanins, and antioxidant capacity of colored maize (Zea mays L.) kernels. J Agric Food Chem. 60:1224-1231. 